\title{
Hubungan Kompetensi Pedagogik dengan Kreativitas Guru
}

\author{
Febriana Ramadhan, Sodikin, Ulfah Fajarini \\ UIN Syarif Hidayatullah Jakarta \\ email: sodikin.ips@uinjkt.ac.id
}

Naskah diterima: 16 Desember 2019, direvisi: 21 Desember 2019, disetujui: 31 Desember 2019

\begin{abstract}
This study aims to look at the relationship between pedagogic competence and teacher creativity. This research was conducted using a survey method for social science teachers in the Sawangan and Bojongsari sub-districts, Depok City. The data analysis technique uses a statistical correlation test and simple linear regression. Hypothesis testing is performed at the 0.05 and 0.01 significance levels. The results showed that there was a very significant positive relationship between pedagogical competence and teacher creativity. Regression equation $\hat{Y}=68.95+2.84$ with the correlation coefficient ry. $1=0.619$, and the coefficient of determination r2y. $1=0.383$. The results of such studies indicate that pedagogical competence correlates with increasing teacher creativity.
\end{abstract}

Keywords: Pedagogical Competence, And Teacher Creativity.

\begin{abstract}
Abstrak
Penelitian ini bertujuan untuk melihat hubungan antara kompetensi pedagogik dengan kreativitas guru. Penelitian ini dilaksanakan dengan menggunakan metode survei pada guru-guru IPS di wilayah Kecamatan Sawangan dan Kecamatan Bojongsari, Kota Depok. Adapun teknik analisis data menggunakan uji statistik korelasi dan regresi linear sederhana. Pengujian hipotesis dilakukan pada taraf signifikansi 0,05 dan 0,01. Hasil penelitian menunjukkan bahwa terdapat hubungan positif yang sangat signifikan antara kompetensi pedagogik dengan kreativitas guru. Persamaan regresi $\hat{Y}=68,95+$ 2,84 dengan nilai koefisien korelasi ry. $1=0,619$, serta nilai koefisien determinasi r2y.1 $=0,383$. Hasil penelitian seperti itu menunjukkan bahwa kompetensi pedagogik berkorelasi terhadap peningkatan kreativitas guru.
\end{abstract}

Kata Kunci: Kompetensi Pedagogik, dan Kreativitas Guru 


\section{PENDAHULUAN}

Secara ideal, pembelajaran Ilmu Pengetahuan Sosial pada jenjang Sekolah Menengah Pertama diharapkan mampu mengembangkan berbagai keterampilan peserta didik, seperti kemampuan berpikir kritis, memecahkan masalah, mengaitkan konsep-konsep pembelajaran dengan kehidupan nyata dalam masyarakat, dan sebagainya. Hal ini tentu hanya dapat terwujud jika guru mampu mengembangkan pembelajaran yang berorientasi pada peserta didik (student center). Hal ini sejalan dengan pendapat A Kosasih Djahiri dalam Sapriya, bahwa pembelajaran Ilmu Pengetahuan Sosial mengutamakan peran aktif siswa melalui proses belajar inquiri, agar siswa mampu mengembangkan berpikir kritis, rasional, dan analisis, mengaitkan materi pembelajaran dengan kehidupan nyata di masyarakat (Sapriya, 2006: 8).

Tantangan pembelajaran Ilmu Pengetahuan Sosial sebagaimana tergambar di atas, menuntut guru harus selalu mengembangkan kreativitas dalam melaksanakan tugasnya sebagai pendidik. Kreativitas itu dapat diwujudkan antara lain melalui: upaya pengembangan diri secara terus menerus, terbuka terhadap pengalaman baru, berani mengambil resiko, melakukan hal-hal yang baru atau berbeda dari yang sebelumnya. Muara dari semua upaya tersebut adalah agar dapat memberikan layanan pembelajaran yang terbaik bagi peserta didik sehingga dapat mencapai tujuan pembelajaran secara efektif.

Namun dalam kenyataannya, harapan tentang profil ideal guru Ilmu Pengetahuan Sosial sebagaimana yang terurai di atas belum dapat terwujud sepenuhnya. Pembelajaran yang terjadi di ruang-ruang kelas masih ditandai oleh teacher center, monoton, metode pembelajaran yang didominasi oleh ceramah dan kurang variatif, hanya memanfaatkan buku teks sebagai sumber belajar satu-satunya, pembelajaran lebih menekankan hafalan dan kognitif, kurang kontekstual, dan sebagainya. Selain itu masih banyak guru yang belum mampu melaksanakan pembelajaran Ilmu Pengetahuan Sosial secara terpadu. Realitas di lapangan, berdasarkan hasil survei pendahuluan melalui penyebaran angket terhadap 10 orang guru Ilmu Pengetahuan Sosial yang berasal dari berbagai sekolah di Kecamatan Sawangan dan Bojongsari Kota Depok pada bulan September 2015 mengindikasikan bahwa kreativitas guru masih rendah. Persentase guru yang masih monoton dalam memulai pembelajaran dan belum melakukan improvisasi dalam KBM agar dapat mencapai tujuan pembelajaran secara efektif mencapai 55,56\%. Persentase guru yang belum mengembangkan diri secara berkelanjutan mencapai 57,78\%. Persentase guru yang belum memiliki kepercayaan diri yang tinggi dalam menerapkan ide atau gagasan baru dalam pembelajaran mencapai $66,67 \%$. Sementara itu, persentase guru yang tidak berani mengambil resiko dalam pembelajaran mencapai $60,00 \%$. Sedangkan persentase untuk guru yang belum berpandangan positif terhadap pengalaman baru mencapai 62,22\%. Padahal kreativitas guru memiliki peranan yang penting dalam mewujudkan tujuan pendidikan. Peserta didik yang kreatif hanya akan dapat dihasilkan melalui pembelajaran yang difasilitasi oleh guru yang kreatif, sehingga diharapkan dapat menghasilkan lulusan yang berkualitas. Berdasarkan permasalahan tersebut perlunya dilakukan penelitian terkait hubungan kompetensi pedagogik dengan kerativitas guru dengan mengambil studi kasus pada guru mata pelajaran Ilmu Pengetahuan Sosial di Kecamatan Sawangan dan Bojongsari Kota Depok. Adapun tujuan penelitian yaitu untuk mengetahui korelasi antara kompetensi pedagogik dengan kreativitas guru.

\section{LANDASAN TEORI}

\section{Pengertian Kreativitas}

Kreativitas merupakan sebuah konsep yang multidimensional dan kompleks. Hal tersebut terbukti dari banyaknya kajian kreativitas dari berbagai perspektif, seperti pendekatan psikologis, sosiologis, maupun kombinasi keduanya. Karena sifatnya yang demikian, menjadi tidak mudah untuk merumuskan sebuah definisi yang operasional. Namun yang pasti pada dasarnya setiap orang yang normal memiliki potensi kreativitas, hanya frekuensi dan kualitasnya saja yang berbeda-beda. Hal ini sejalan dengan pendapat Devito yang 
mengatakan bahwa kreativitas merupakan suatu kemampuan yang dimiliki oleh setiap orang dengan tingkat yang berbeda-beda.

Sementara itu menurut Munandar (2009), ada empat makna pentingnya pengembangan kreativitas bagi setiap orang, yaitu:

1. Dengan kreativitas orang dapat mengaktualisasikan diri;

2. Dapat melihat bermacam-macam kemungkinan penyelesaian masalah;

3. Bermanfaat bagi diri sendiri dan lingkungan; dan

4. Memungkinkan manusia meningkatkan kualitas hidupnya.

\section{Pentingnya Kreativitas bagi Guru}

Kaitan antara kreativitas dengan dunia pendidikan sudah banyak dikaji oleh para ahli, Mulyasa yang mengutip pernyataan Piaget, "The principle goal of education is to create man who are capable of doing new things, not simply of repeating what other generations have done - man who are creative, inventive, and discoverers". Kalimat tersebut menunjukkan betapa kreativitas dan orangorang kreatif merupakan indikator penting dalam keberhasilan pendidikan. Manusiamanusia kreatif sebagai output pendidikan hanya akan dapat dihasilkan melalui proses kreatif yang selalu merangsang perkembangan kreativitas.

Paragraf di atas secara tidak langsung mengungkapkan pentingnya kreativitas bagi seorang guru. Tanpa bermaksud mengurangi arti penting komponen yang lain, peran guru sebagai agen pembelajaran sangat strategis untuk mewujudkan tujuan pendidikan nasional. Pada sisi lain, perkembangan di era globalisasi saat ini yang mencakup hampir seluruh aspek kehidupan secara langsung maupun tidak juga telah mempengaruhi dunia pendidikan. Perkembangan ilmu pengetahuan yang didukung oleh teknologi informasi dan komunikasi semakin mempermudah setiap orang untuk mengakses berbagai informasi terbaru.

Fenomena di atas tentu menjadi sebuah tantangan sekaligus peluang bagi guru. Guru harus semakin maksimal dalam melaksanakan tugas dan fungsinya dengan cara selalu mengembangkan diri, terbuka terhadap penga- laman baru, memiliki semangat kerja yang tinggi, tidak mudah menyerah, berpikir positif, dan berupaya menemukan berbagai alternatif dalam menyelesaikan masalah yang dihadapi. Intinya adalah sosok guru yang selalu mengembangkan kreativitas sesuai tuntutan profesinya.

Keberadaan guru yang kreatif sebagaimana diuraikan di atas juga sangat dibutuhkan dalam mata pelajaran Ilmu Pengetahuan Sosial pada jenjang SMP. Merujuk pada kurikulum, disebutkan bahwa tujuan pembelajaran Ilmu Pengetahuan Sosial pada jenjang SMP adalah untuk mengembangkan berbagai keterampilan peserta didik, seperti kemampuan berpikir kritis, memecahkan masalah. Selain itu peserta didik juga diharapkan mampu mengaitkan konsep-konsep yang dipelajari dengan fenomena kehidupan nyata dalam masyarakat. Hal ini tentu tidak akan tercapai jika pembelajaran yang terjadi di kelas-kelas hanya berupa transfer of knowledge yang didominasi oleh metode ceramah. Hasil kajian Skeel dari berbagai hasil penelitian menunjukkan bahwa nilai peserta didik dalam mata pelajaran Ilmu Pengetahuan Sosial atau social studies sangat rendah dibandingkan dengan mata pelajaran lain. Salah satu penyebabnya adalah peserta didik cenderung merasa bosan karena pembelajaran didominasi oleh motode ceramah.

\section{Kompetensi Pedagogik Guru}

Dengan berlakunya Undang-Undang Nomor 14 Tahun 2005 tentang Guru dan Dosen telah meningkatkan status guru menjadi pendidik profesional. Tugas utamanya adalah mendidik, mengajar, membimbing, mengarahkan, melatih, menilai, dan mengevaluasi peserta didik pada jenjang pendidikan dasar dan menengah. Kata profesional mengisyaratkan bahwa pekerjaan atau kegiatan yang dilakukan seorang guru dapat menjadi sumber penghasilan kehidupan, namun harus memenuhi persyaratan-persyaratan tertentu. Persyaratan tersebut adalah memiliki kualifikasi akademik, keahlian, kemahiran, dan kecakapan tertentu. Persyaratan minimal secara akademik seorang guru adalah Sarjana (S1) atau Diploma 4, serta menguasai kompetensi guru secara utuh meliputi kompetensi pedagogik, kepribadian, 
profesional, dan sosial. Tujuan ditetapkannya persyaratan penguasaan kompetensi bagi guru tersebut adalah untuk menjamin keterlaksanaan tugas sebagai pendidik secara profesional.

Penguasaan guru terhadap kompetensi pedagogik ini sangat penting karena terkait langsung dengan aktivitas pembelajaran. Menurut Rusman (2010), penguasaan kompetensi pedagogik penting bagi guru agar kegiatan pembelajaran lebih bermakna dan berhasil guna. Pernyataan ini juga didukung oleh Victor C.X. Wang (2010), bahwa tanpa pengetahuan tentang pedagogik, setiap kegiatan pembelajaran hanya akan menyebabkan aktivitas yang ceroboh, apalagi pengajaran yang efektif. Berdasarkan hasil kajian kepustakaan, ditemukan banyak sekali definisi yang telah dikemukakan oleh para ahli tentang pengertian kompetensi pedagogik serta lingkupnya. Menurut Janawi, kompetensi pedagogik adalah kemampuan guru berkenaan dengan penguasaan teoritis dan proses aplikasinya dalam pembelajaran.

\section{METODOLOGI PENELITIAN}

Penelitian ini dilaksanakan di Sekolah Menengah Pertama (SMP) di Kecamatan Sawangan dan Bojongsari Kota Depok selama 9 (sembilan) bulan yaitu dari bulan Desember 2015 sampai dengan bulan Agustus 2016. Metode yang digunakan dalam penelitian ini adalah metode survei dengan pendekatan korelasional, yaitu jenis penelitian yang berupaya untuk membuktikan ada atau tidaknya hubungan antara variabel bebas dengan variabel terikat. Variabel-variabel yang dimaksud, yaitu: Kompetensi pedagogik sebagai variabel bebas (X) dan Kreativitas Guru sebagai variabel terikat $(Y)$. Lebih jelas seperti disajikan pada Gambar 1

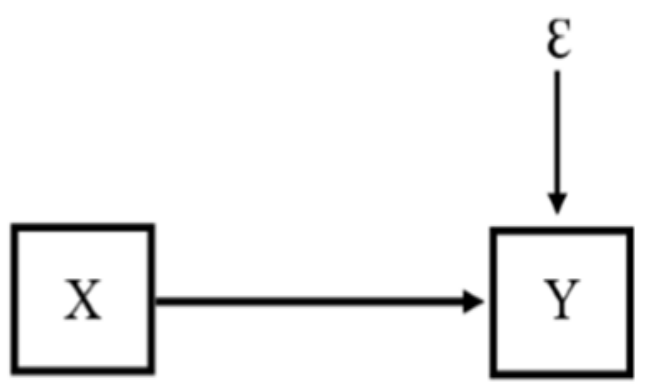

Gambar 1 Konstelasi Hubungan antar Variabel
Keterangan:

$\mathrm{X}$ : Kompetensi Pedagogik

$\mathrm{Y}:$ Kreativitas Guru

$\mathcal{E}$ : Variabel lain yang diduga memiliki hubungan dengan kreativitas guru

Populasi dalam penelitian ini adalah seluruh guru SMP mata pelajaran Ilmu Pengetahuan Sosial dalam wilayah Kecamatan Sawangan dan Bojongsari, kota Depok berjumlah 33 orang yang berasal dari 24 Sekolah. Sedangkan pengambilan sampel dalam penelitian ini menggunakan rumus yang digunakan oleh Solvin dengan tingkat kepercayaan 95\% (tingkat kesalahan 5\%), sehingga diperoleh jumlah sampel sebanyak 30 guru. Teknik pengumpulan data pada penelitian ini menggunakan instrumen yang disusun berdasarkan indikator setiap variabel. Pengumpulan data untuk variabel kreativitas guru (Y) berbentuk non tes berupa kuesioner dengan menggunakan skala penilaian 1-5. Sedangkan pengumpulan data untuk variabel kompetensi pedagogik $(\mathrm{X})$ dilakukan melalui tes terstruktur berupa pertanyaan pilihan ganda. Sebelum diberikan kepada responden yang diberikan sampel pada penelitian ini, instrumen terlebih dahulu divalidasi dan diuji reliabilitasnya. Hipotesis penelitian ini adalah sebagai berikut:

H0: $\sum \mathrm{y} 1=0 \quad$ Tidak terdapat hubungan antara Kompetensi Pedagogik dengan Kreativitas Guru

H1: $\sum y 1>0$ Terdapat hubungan positif antara Kompetensi Pedagogik dengan Kreativitas Guru

Keterangan

H0 : Hipotesis Nol (Hipotesis statistik)

H1 : Hipotesis Alternatif (Hipotesis statistik)

$\sum y 1$ : Koefisien kolerasi antara variabel kompetensi pedagogik dengan variabel kreativitas guru.

Koefisien korelasi dihitung dengan menggunakan rumus product moment person. Setelah diketahui korelasi antara variabel $\mathrm{X}$ dan $\mathrm{Y}$, selanjutnya dilakukan uji keberartian korelasi dengan menggunakan uji t. 


\section{HASIL DAN PEMBAHASAN}

\section{Deskripsi Tempat Penelitian}

Penelitian ini dilakukan di Kecamatan Sawangan dan Bojongsari Kota Depok. Secara umum, Depok adalah sebuah kota yang terletak di Selatan Jakarta, yakni antara Jakarta dan Bogor. Dahulu Depok adalah Kecamatan dalam wilayah Kabupaten Bogor, yang kemudian mendapat status kota administratif pada tahun 1982. Sejak 20 April 1999, Depok ditetapkan menjadi kota yang terpisah dari Kabupaten Bogor. Kota Depok terdiri atas 11 Kecamatan yang terbagi menjadi 63 kelurahan hasil pemekaran. Adapun sekolah yang dijadikan tempat penelitian seperti terlihat pada Tabel 1

Tabel 1 Lokasi Penelitian

\begin{tabular}{|c|l|}
\hline NO & \multicolumn{1}{|c|}{ NAMA SEKOLAH } \\
\hline 1 & SMP Al-Hasra \\
\hline 2 & SMP Darul Ulum \\
\hline 3 & SMP Terpadu Darussalam \\
\hline 4 & SMP Islamiyah Serua \\
\hline 5 & SMPN 14 Depok \\
\hline 6 & SMP Permata Bunda Reni Jaya \\
\hline 7 & SMP PGRI 363 Pondok Petir \\
\hline 8 & SMP Raudhatul Falah \\
\hline 9 & SMP Bina Insan Cendikia \\
\hline 10 & SMP Islam Al-Ihsan \\
\hline 11 & SMP Islam Al-Ma'arif \\
\hline 12 & SMP Arrihlah \\
\hline 13 & SMP Darul Qur'an \\
\hline 14 & SMP Hidayatul Ihsan \\
\hline 15 & SMP Islam Plus Az-Zahra \\
\hline 16 & SMPN 10 Depok \\
\hline 17 & SMPN 18 Depok \\
\hline 18 & SMP Daarun Ni'mah \\
\hline 19 & SMP Yapan \\
\hline 20 & SMP Muhammadiyah 29 \\
\hline 21 & SMP Islamiyah Sawangan \\
\hline 22 & SMP IT Amec \\
\hline 23 & SMP IT Daarul Rahman \\
\hline 24 & SMP IT Darul Hikam \\
\hline & \\
\hline
\end{tabular}

Uji Normalitas Galat Baku Taksiran (Y $\hat{Y})$ Persamaan Regresi antara Variabel Kompetensi Pedagogik (X) dengan Kreativitas Guru (Y)
Hasil uji normalitas galat baku taksiran (Y - $\hat{Y}$ ) persamaan regresi antara kompetensi pedagogik $(\mathrm{X})$ dengan variabel kreativitas guru (Y) melalui perhitungan didapatkan nilai Lhitung $=0,117$, sementara Ltabel pada taraf signifikansi 0,05 adalah 0,159. Maka dapat dilihat bahwa $\mathrm{L}$ hitung $<\mathrm{L}$ tabel yaitu $0,117<$ 0,159. Dengan demikian Galat Baku Taksiran $Y-\hat{Y}$ persamaan regresi antara variabel kompetensi pedagogik (X) dengan variabel kreativitas guru $(\mathrm{Y})$ berasal dari populasi yang berdistribusi normal. Rangkuman uji normalitas data dapat dilihat pada Tabel 2.

Tabel 2 Rangkuman Uji Normalitas Data

\begin{tabular}{|c|c|c|c|}
\hline $\begin{array}{c}\text { Galat Baku } \\
\text { Taksiran }\end{array}$ & $\mathbf{L}_{\text {hitung }}$ & $\mathbf{L}_{\text {tabel }}$ & Kesimpulan \\
\hline $\mathrm{Y}-\hat{\mathrm{Y}}$ & 0,117 & 0,159 & Normal \\
\hline Syarat Normal $\mathrm{L}_{\text {hitung }}<\mathrm{L}_{\text {tabel }}$ \\
\hline
\end{tabular}

\section{Pengujian Hipotesis}

Pengujian hipotesis dimaksudkan untuk mengetahui hubungan antara kompetensi pedagogik (X) dengan kreativitas guru (Y). Pengujian hipotesis diawali dengan melakukan uji signifikansi dan linearitas terhadap persamaan regresi. Kemudian dilakukan uji korelasi sederhana untuk mengetahui koefisien korelasi antar variabel serta signifikansinya. Analisis regresi linear sederhana antara variabel kompetensi pedagogik (X) dengan variabel kreativitas guru (Y) menghasilkan persamaan regresi $\mathrm{Y}=68,95+2,84 \mathrm{X}$. Uji signifikansi dan linearitas terhadap persamaan regresi dilakukan dengan menggunakan uji F. Hubungan dinyatakan signifikan apabila nilai Fhitung $>$ Ftabel pada taraf signifikansi 0,05. Sedangkan persamaan regresi dikatakan linear apabila nilai Fhitung $<$ Ftabel. Berdasarkan uji dengan menggunakan analisis varians (ANOVA) diperoleh hasil seperti tertera pada tabel berikut ini. Rangkuman uji signifikansi dan kelinearan persamaan regresi dapat dilihat pada Tabel 3. 
Tabel 3 Rangkuman Uji Signifikansi dan Kelinearan Persamaan Regresi

\begin{tabular}{|l|c|c|c|l|}
\hline \multirow{2}{*}{ Uji } & \multirow{2}{*}{$\mathbf{F}_{\text {hitung }}$} & \multicolumn{2}{|c|}{$\mathbf{F}_{\text {tabel }}$} & Kesimpulan \\
\cline { 3 - 4 } & & $\boldsymbol{\alpha}=\mathbf{0 , 0 5}$ & $\boldsymbol{\alpha}=\mathbf{0 , 0 1}$ & \\
\hline Signifikansi & 20,170 & 4,20 & 7,64 & Sangat Signifikan $F_{\text {hitung }}>F_{\text {tabel }}$ \\
\hline Kelineran & 1,563 & 2,45 & 3,56 & Non Signifikan (Regresi Linear) $F_{\text {hitung }}<\mathrm{F}_{\text {tabel }}$ \\
\hline
\end{tabular}

Berdasarkan tabel di atas, terlihat bahwa harga Fhitung sebesar 20,170 sedangkan Ftabel pada taraf signifikansi 0,05 adalah 4,20 dan pada taraf signifikansi 0,01 adalah 7,64. Dengan demikian harga Fhitung lebih besar dari Ftabel. Hal ini menunjukkan bahwa persamaan regresi $\hat{\mathrm{Y}}=68,95+2,84 \mathrm{X}$ dapat digunakan sebagai acuan untuk memprediksi kreativitas guru melalui kompetensi pedagogik.

Selanjutnya pengujian linearitas regresi mendapatkan hasil Fhitung $=1,563$ lebih kecil dari Ftabel dengan taraf signifikansi 0,05 yaitu 2,45 dan Ftabel dengan taraf signifikansi 0,01 yaitu 3,56. Dengan demikian, dapat dikatakan bahwa persamaan regresi $\mathrm{Y}=68,95+2,84 \mathrm{X}$ adalah linear. Persamaan regresi tersebut menunjukkan bahwa setiap kenaikan satu unit skor kompetensi pedagogik (X) akan menyebabkan kenaikkan 2,84 unit skor kreativitas guru $(Y)$ pada konstanta 68,95. Secara grafis, persamaan regresi antara kompetensi pedagogik $(\mathrm{X})$ dan kreativitas guru $(\mathrm{Y})$ dapat dilihat pada Gambar 2.

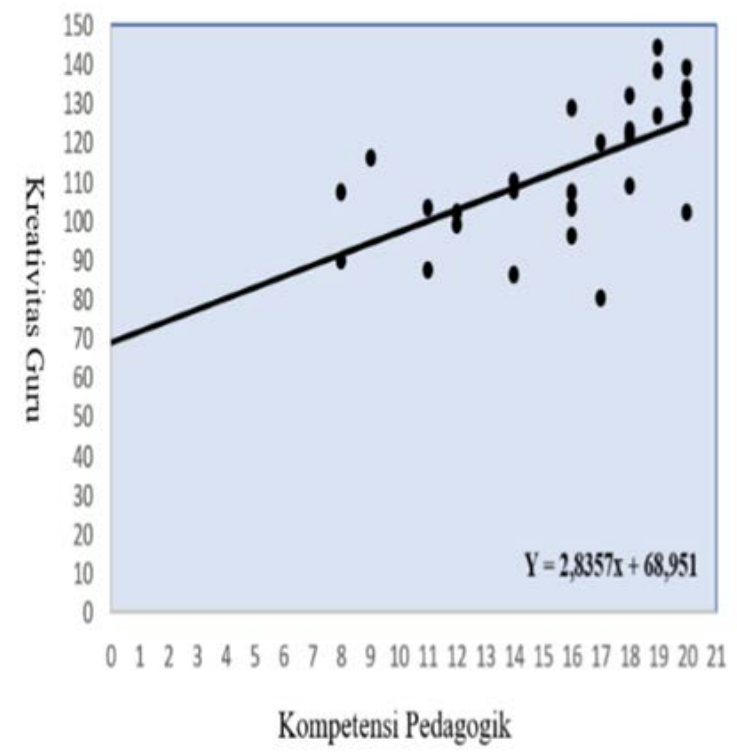

Gambar 2 Diagram Pencar Regresi antara Kompetensi Pedagogik (X) dengan Kreativitas Guru (Y)
Kekuatan hubungan antara variabel kompetensi pedagogik $(\mathrm{X})$ dengan kreativitas guru (Y) ditunjukkan oleh koefisien korelasi ry.1 = 0,619 dengan koefisien determinasi $\mathrm{r}^{2} \mathrm{y} \cdot 1=$ 0,383 . Hal ini berarti bahwa kompetensi pedagogik memberikan kontribusi sebesar 38,3\% terhadap kreativitas guru. Sedangkan 61,7\% kreativitas guru dipengaruhi oleh faktor lain. Secara grafis, kontribusi kompetensi pedagogik terhadap kreativitas guru dapat dilihat pada Gambar 3.

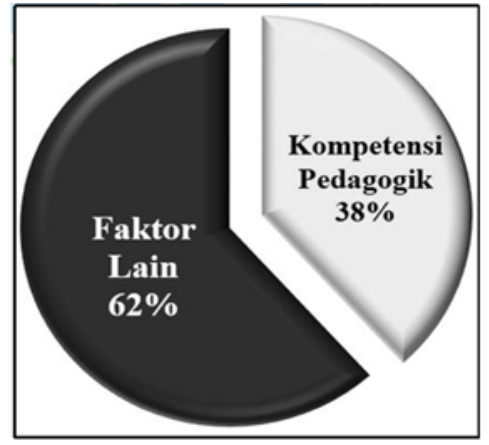

Gambar 3 Kontribusi kompetensi pedagogik terhadap kreativitas guru

Selanjutnya, untuk menguji signifikansi hubungan positif antara variabel kompetensi pedagogik (X) dengan kreativitas guru (Y) diperlukan uji signifikansi koefisien korelasi, yaitu Uji t. Jika t hitung $>\mathrm{t}$ tabel maka koefisien korelasi dinyatakan Signifikan. Berdasarkan hasil penghitungan, diperoleh $\mathrm{t}$ hitung $=4,168$ sedangkan $\mathrm{t}$ tabel dengan taraf signifikansi 0,05 $=2,04$ dan $\mathrm{t}$ tabel dengan taraf signifikansi 0,01 $=2,75$. Sehingga, koefisien korelasi antara variabel kompetensi pedagogik dengan kreativitas guru dinyatakan sangat signifikan pada taraf signifikansi 0,05. Dengan demikian, dapat disimpulkan bahwa hipotesis nol (H0) ditolak dan hipotesis alternatif (H1) diterima. Artinya terdapat hubungan positif antara kompetensi pedagogik dengan kreativitas guru. Hasil uji signifikansi koefisien korelasi antara kompetensi pedagogik dengan kreativitas guru dapat dilihat pada Tabel 4 . 
Tabel 4 Hasil Perhitungan Uji Signifikansi Korelasi Variabel X dan Y

\begin{tabular}{|c|c|c|c|c|c|}
\hline Koefisien & $\mathbf{N}$ & \multirow{2}{*}{$\mathbf{t}_{\text {hitung }}$} & \multicolumn{2}{|c|}{$\mathbf{t}_{\text {tabel }}$} & Kesimpulan \\
\cline { 4 - 5 } & & & $\boldsymbol{\alpha}=\mathbf{0 , 0 1}$ & $\boldsymbol{\alpha}=\mathbf{0 , 0 5}$ & \\
\hline 0,619 & 30 & 4,168 & 2,75 & 2,04 & Sangat Signifikan \\
\hline \multicolumn{5}{|c|}{ Persyaratan uji taraf signifikansi : $\mathbf{t}_{\text {hitung }}>\mathbf{t}_{\text {tabel }}$} \\
\hline
\end{tabular}

Hal ini bermakna bahwa kontribusi kompetensi pedagogik (X) dalam meningkatkan kreativitas guru (Y) adalah sebesar 38,3\%. Sedangkan $61,7 \%$ disebabkan oleh faktor lain. Kenyataan ini menggambarkan bahwa kreativitas guru dipengaruhi oleh tinggi atau rendahnya kompetensi pedagogik. Selain menguasai kompetensi pedagogik dengan baik, kreativitas juga merupakan hal yang harus dimiliki guru agar dapat melaksanakan tugas profesional dengan baik. Guru yang kreatif akan selalu berupaya mengaktualisasikan diri untuk mengatasi berbagai permasalahan yang terkait dengan tugas profesionalnya melalui cara-cara yang baru atau relatif berbeda. Sosok guru kreatif tidak akan melaksanakan tugas sebagai rutinitas saja. Sebagaimana dikemukakan oleh E. Mulyasa bahwa kreativitas akan menunjukkan bahwa apa yang dilakukan guru sekarang lebih baik dari yang telah dilakukan sebelumnya (Mulyasa, 2008: 52). Guru yang kreatif akan ditandai oleh tingginya inisiatif pembelajaran, selalu berupaya mengembangkan diri, memiliki rasa percaya diri yang tinggi, berani mengambil resiko, serta terbuka terhadap pengalaman baru.

Penguasaan guru terhadap kompetensi pedagogik akan mempengaruhi kreativitas. Guru kreatif yang ditandai oleh kaya dengan inisiatif pembelajaran tentu dibekali oleh pemahaman yang baik terkait dengan keberagaman peserta didik dalam berbagai aspek. Pemahaman inilah yang dijadikan dasar untuk merancang pembelajaran yang berbasis pada teoriteori dan prinsip pembelajaran yang mendidik. Berbekal pada teori-teori dan prinsip pembelajaran ini pula guru dapat memilih model atau metode pembelajaran yang paling efektif yang berbasis pada kebutuhan dan potensi peserta didik.

Selanjutnya, sebuah perencanaan pembelajaran yang telah disusun dengan baik belum tentu selalu dapat diimplementasikan sesuai harapan. Sehingga tidak mengherankan jika Anna Herbert mengatakan bahwa pembelajaran tidak dapat direproduksi begitu saja. Sebuah pengalaman keberhasilan dalam pembelajaran dipengaruhi oleh banyak faktor, sehingga tidak dapat begitu saja diterapkan dalam konteks tempat dan waktu yang berbeda, walaupun dengan isi yang serupa (Anna, 2010: 70-71). Dalam hal inilah pentingnya kreativitas guru agar dapat mengatasi masalah yang dihadapi secara efektif melalui pengembangan diri, terbuka terhadap pengalaman baru, memiliki rasa percaya diri yang tinggi disertai keberanian mengambil resiko.

Pentingnya upaya memupuk kreativitas guru melalui pengembangan diri secara terusmenerus serta keterbukaan terhadap pengalaman baru ini juga sejalan dengan teori tentang kreativitas yang dikemukakan oleh Dedi Supriadi, bahwa setiap orang lahir dengan potensi kreatif dan tidak ada orang yang sama sekali tidak memiliki kreativitas, yang diperlukan adalah bagaimana mengembangkannya (Dedi, 1997: 16). Peningkatan kemampuan kompetensi pedagogik melalui pengembangan wawasan, diharapkan dapat meningkatkan kreativitas guru adalah dengan meningkatkan kompetensi pedagogik. Sejalan dengan itu, dalam penelitian relevan yang dilakukan oleh Nelfuad dan Haryati pun menyatakan bahwa kompetensi pedagogik dapat meningkatkan kreativitas guru.

\section{KESIMPULAN}

Berdasarkan data empirik di lapangan, hasil analisis, dan pembahasan penelitian, diperoleh kesimpulan bahwa terdapat hubungan positif dan sangat signifikan antara variabel kompetensi pedagogik (X) dengan variabel kreativitas guru (Y) yang ditunjukkan melalui persamaan regresi $\hat{\mathrm{Y}}=68,95+2,84 \mathrm{X}$. dan 
nilai koefisien korelasi ry.1 $=0,619$ serta nilai koefisien determinasi $\mathrm{r}^{2} \mathrm{y} \cdot 1=0,383$ atau $38,3 \%$. Hal ini berarti bahwa kompetensi pedagogik memberikan kontribusi terhadap kreativitas guru sebesar $38,3 \%$.

\section{DAFTAR PUSTAKA}

Anna Hebert. (2010). The Pedagogy of Creativity. New York: Rouletge Taylor and Prancis Group

C.X. Wang Victor, et, al. (2012). Pedagogical and Andragogical: Teaching and Learning With Information, Communication, Technologies. USE: IGI Global

Heryanti. (2015). Hubungan Kompetensi Pedagogik dan Kecerdasan Emosional dengan Kreativitas Kerja Guru. Bogor: Tesis Program Pasca Sarjana Universitas Pakuan

Mansoer, Masri dan Elin Driana. (2009). Statistik Sosial. Jakarta: Ushul Press
Mulyasa, E. (2008). Menjadi Guru Professional: Menciptakan Pembelajaran Kreatif dan Menyenangkan. Bandung: Remaja Rosda Karya

Mulyasa, E. (2012). Standar Kompetensi dan Sertifikasi Guru. Bandung: PT Remaja Rosdakarya

Munandar, Utami. Pengembangan Kreativitas Anak Berbakat. Jakarta: Rineka Cipta, 2009.

Rusman. (2010). Model-model Pembelajaran: Mengembangkan Profesionalisme Guru. Depok: Radja Grafindo Persada

Sapriya, dkk. (2006). Pembelajaran dan Evaluasi Hasil Belajar IPS. Bandung: UPI Press

Supriadi, Dedi. (1997). Kreativitas, Kebudayaan, dan Perkembangan IPTEK. Bandung: CV Alfabeta

UU RI No. 14 Tahun 2005 tentang Guru dan Dosen, 30 Desember 2005. 